\title{
Cortical Cell Layer of the Cerebellum
}

National Cancer Institute

\section{Source}

National Cancer Institute. Cortical Cell Layer of the Cerebellum. NCI Thesaurus. Code C49137.

The cortical cell layer of the cerebellum. It consists of the granular layer, molecular layer, and Purkinje cell layer. 